\title{
Molecular, Physico-Chemical, and Sensory Characterization of the Traditional Spanish Apple Variety "Pero de Cehegín"
}

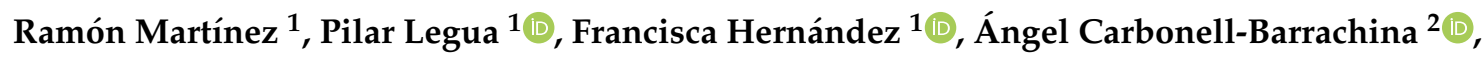 \\ Yolanda Gogorcena ${ }^{3}{ }^{\mathbb{D}}$, Juan J. Martínez-Nicolás ${ }^{1}$ and Pablo Melgarejo ${ }^{1, *}$ \\ 1 Plant Production and Microbiology Department, Orihuela Polytechnical High School (EPSO), \\ Miguel Hernández University of Elche, Ctra de Beniel, km 3.2, 03312 Orihuela, Spain; \\ ramonmartinez74@hotmail.com (R.M.); p.legua@umh.es (P.L.); francisca.hernandez@umh.es (F.H.); \\ juanjose.martinez@umh.es (J.J.M.-N.) \\ 2 Department of Agro-Food Technology, Orihuela Polytechnical High School (EPSO), \\ Miguel Hernández University of Elche, Ctra. Beniel Km 3.2, 03312 Orihuela, Spain; \\ angel.carbonell@umh.es \\ 3 Departament of Pomology, Estación Experimental de Aula Dei (CSIC), Avenida de Montañana 1005, \\ 50059 Zaragoza, Spain; aoiz@eead.csic.es \\ * Correspondence: pablo.melgarejo@umh.es; Tel.: +34-966-74-69-49
}

Received: 10 June 2020; Accepted: 23 July 2020; Published: 28 July 2020

\begin{abstract}
The "Pero de Cehegín" is an ancient local variety of apple grown in Murcia (Spain). In this study, microsatellites markers showed evidence of a unique profile that has never been reported before in other Spanish apple germplasm collections. Five "Pero de Cehegín" clones were evaluated and compared with two commercial apple varieties, "Fuji" and "Golden Delicious", to assess its marketing potential. For this, the physical (weight, height, and width of the fruit, moisture content, firmness, and color of the fruit, among others), and chemical (total soluble solids, total acidity, and maturity index) properties of the fruits were evaluated. In addition, the content of bioactive compounds such as total polyphenol content, total antioxidant activity using the $\mathrm{ABTS}^{+}, \mathrm{DPPH}^{\bullet}$, and FRAP methods, and the sugar profile were analyzed, and their sensory profile was also evaluated. Physico-chemical differences were found within the "Pero de Cehegín" clones and between the commercial varieties. "Pero de Cehegín" had a high firmness, high total soluble solids, very low total acidity, high FRAP antioxidant capacity, and more sucrose content in comparison with "Fuji" and "Golden Delicious". These distinctive characteristics and the good appearance of the fruit make this variety a marketable product that will increase the offering of traditional, local, but underutilized fruit varieties.
\end{abstract}

Keywords: bioactive compounds; diversity; genetic resources; malus $\times$ domestica borkh; SSR markers

\section{Introduction}

The Rosaceae family, to which the genus Malus belongs, is widely represented in the European flora [1]. It seems that most of the cultivated apple trees grown for the production of both table and cider apples come from hybrids from different species, such as Malus dasyphylla Borkh that originally came from Asia [2] and the European wild apple (Malus sylvestris Mill.); both species could be considered as the origin of the cultivated or domestic apple tree (Malus domestica Borkh.) [3,4] and some gene flow between them has been described [5].

Apple was the third-most important fruit produced and eaten around the world with a production of 86.1 million $t$ in 2018, of which 19.6 million $t$ corresponded to Europe. The largest producer was China, representing around $45.5 \%$ of the world's total production. The US was the second-largest 
producer with 5.4\%, followed by Poland (4.6\%), Turkey (4.2\%), Iran (2.9\%), and Italy (2.8\%). Spain, with 0.56 million tons was the 10th European producer [6]. In Spain, the apple represents the third-most important crop after citrus fruits and the group of peaches and nectarines [7], and is also one of the most imported fruits along with pineapple, banana, and kiwi [8]. The main apple production areas are the regions of Catalonia and Aragon, with a very important polarization in the production of the group "Golden". In the 2008-2018 period, the "Golden Delicious" variety accounted for 45\% of the national production [7].

The "Pero de Cehegín", framed within the "common cultivated apple trees" in the genus and species Malus domestica Borkh [9], is a local variety of apple tree, cultivated mainly in the northwest of the Murcia province (Spain). The reason for its name is that its cultivation has historically been carried out almost exclusively in the municipality of Cehegín, which has a suitable habitat for this apple variety. The fruits (Figure 1) are medium size, longer than wide, and flat at the ends of their axis. Before ripening, its color is dark green, and once ripe its changes to a greenish-yellow, being more colored in the sun-exposed area. Its pulp is firm and of great quality, and has an exquisite flavor and a fragrant aroma [10]. The fruit ripening occurs in November [9].

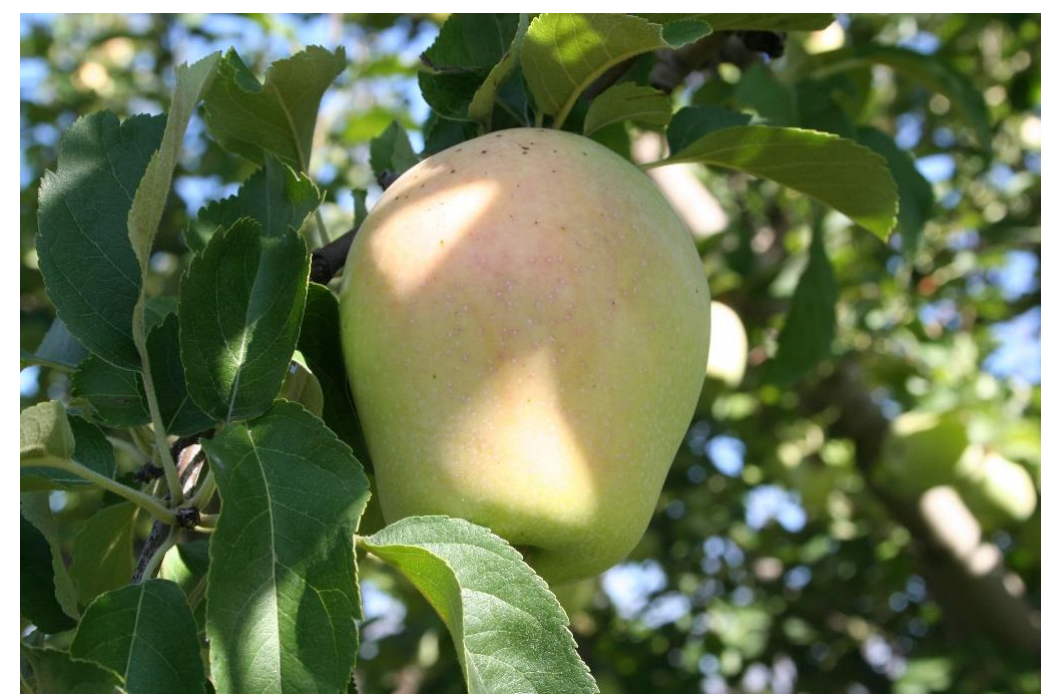

Figure 1. Fruit of "Pero de Cehegín".

Although the denomination of "Pero" has enjoyed some esteem in the cultivation region, the name is usually applied with little precision. Thus, for some local farmers, the "Pero" fruits are characterized by their intense aroma, for others, by a peculiar texture of its pulp, and for others by an elongated, oval, or conical shape, almost resembling a pear. Table 1 shows the differences between "Pero" and "apple" [9].

Table 1. Differences between apple and "Pero de Cehegín".

\begin{tabular}{ccc}
\hline Attribute & Apple & "Pero de Cehegín" \\
\hline Shape & Spherical or flattened & Oval, conical, or heart-shaped \\
Stilar cavity & More or less smooth & Surrounded by several gibbosities \\
Peel thickness & Thin or medium & Thick \\
Aroma & Aromatic & Very aromatic \\
Sweetness & Sweet & Very sweet (acid when grown in the Middle \\
Pulp & From consistent to soft pulp, juicy & European Region) \\
Storage & Refrigerated & Pulp very hard, compact, and mealy \\
& & No need for refrigeration \\
\hline
\end{tabular}

Local varieties are the result of selection through climatic and edaphic adaptation and human action $[11,12]$. However, these traditional varieties have been replaced with new ones of foreign 
origin, which causes a strong genetic erosion in the agricultural heritage. However, these old and local varieties in terms of biodiversity have an extremely high value [13], and as opposed to commercial varieties, often carry specific and uncommon properties that could be interesting to different consumers. Therefore, consumers must understand the kind of properties that distinguish them from standard varieties in the market $[14,15]$. Due to these reasons, the conservation of the local genetic diversity to prevent its disappearance is urgent. Along this line, Martínez [16] carried out the first prospection and selection of the "Pero de Cehegín" in several areas of Cehegín (Murcia, Spain); this work was the beginning of two germplasm collections. Germplasm banks, in their current conception, constitute essential systems for avoiding the loss of genetic biodiversity and, therefore, to guarantee the future of endangered species. The collections are located in two different areas, one in the Higher Polytechnic School of Orihuela, EPSO (UMH) in the province of Alicante, and the other in Cehegín, in the northwest of Murcia region. These collections were extended with the introduction of new clones selected in recent years from different geographic origins, and now total 27 accessions.

The genetic and phenotypic characterization of these traditional varieties will help in the conservation and use in future breeding programs. The molecular characterization of apple collections has been performed in the past using Simple Sequence Repeats (SSR). A high number of microsatellites have been described and used to identify different varieties [17-20] and to assess the genetic diversity in core collections [21-24]. In particular, there are several studies in Spanish germplasm collections [23] but to our knowledge, the "Pero de Cehegín" has not been included yet.

At present, several studies have been published about apple variety characterization from China [25], Portugal [26,27], Romania [14], Argentina [28], Brazil [29], and India [30,31].

Generally, the definition of quality and acceptability of apple fruits by consumers are associated with their sensory appeal and chemical composition [32,33]. The concept of "appearance" includes several external fruit characteristics such as size, shape, absence of defects, and color [33]. The rescue of traditional varieties, with distinctive characteristics and good appearance, will help diversify and enrich the offerings for the consumers' demand for new apples or traditional and local varieties with good nutritional, organoleptic, and morphological characteristics.

Consequently, the present study aims to determine the genetic identity of "Pero de Cehegín" using microsatellite markers and to evaluate the main physicochemical characteristics, bioactive compounds, and sensory profile of five selected clones of "Pero de Cehegín" fruits. The "Pero de Cehegín" properties were compared with those of two commercial varieties ("Fuji" and "Golden Delicious"). The marketing potential of these five clones is also discussed.

\section{Materials and Methods}

\subsection{Experimental Conditions and Plant Material}

For the physicochemical characteristics, bioactive compounds and sensory profile, five clones of "Pero de Cehegín" (identified as P1, P2, P3, P4, P5), Malus domestica, the "Golden Delicious" variety and the "Fuji" variety, were collected from the germplasm bank located in the municipality of Cehegín (Murcia, Spain). Furthermore, the five "Pero de Cehegín" clones were also used for molecular analysis. Aiming to base the molecular characterization of "Pero de Cehegín" and its comparison, two reference varieties were taken, "Fuji" and "Granny Smith", due its international importance as commercial cultivars.

The apple trees were 12 years old and spaced following a $4 \times 2 \mathrm{~m}$ pattern. All the clones were grafted onto the M9 rootstock and grown under standard conditions (with a loam-type soil, fertilizing with a quantity of $2 \mathrm{~kg}$ of organic matter and $2 \mathrm{~kg}$ of complex fertilizer $15 \% \mathrm{~N}-15 \% \mathrm{P}_{2} \mathrm{O}_{5}-15 \% \mathrm{~K}_{2} \mathrm{O}$ per tree and year, and according to Papadakis [34] for a Mediterranean climate). For each clone, 20 fruit samples were randomly collected from three trees (for a total of 60 fruits per clone) avoiding damaged fruits. Harvest was done manually in all clones at their commercial maturity stage, during November 
2017, 10 days after finishing its development and reaching its characteristic color. The fruits were stored refrigerated at $3{ }^{\circ} \mathrm{C}$ until their study a few days later.

\subsection{Polymerase Chain Reaction Amplification and SSR Analyses}

Leaves were collected from the trees of the five "Pero de Cehegín" clones in the Cehegín germplasm bank. Two hundred milligrams were frozen in liquid nitrogen and ground to a fine powder using the mixer mill MM400 (Retsh, Haan Germany) and stored at $-20^{\circ} \mathrm{C}$ until further processing. Genomic DNA was isolated with Qiagen Dneasy Plant Mini kit (Qiagen, Hilden, Germany) according to the manufacturer's instructions. The DNA concentration was determined with a NanoDrop 2000 (Thermo Fisher Scientific, Wilmington, DE, USA) and adjusted to $5 \mathrm{ng} \mathrm{LL}^{-1}$ for multiplex PCR.

PCR reactions were carried out with 13 SSRs, including 11 recommended by the ECP/GR Malus/Pyrus Working Group (European Cooperative Programme for Plant Genetic Resources; Lateur et al. [35] (CH04e05, CH01h10, CH02d08, CH01f02, CH02c11, CH04c07, CH02c09, and CH01h01; GD12, GD147, Hi02c07) plus another two due to their usefulness in discriminating the Spanish varieties (CH05f06 and $\mathrm{CH03d07)} \mathrm{[23].}$

The amplification was performed in a 2700 thermal cycler (Applied Biosystems ${ }^{\circledR}$ ), using three multiplex PCRs A, B, and C; see details [36] in a final volume of $10 \mu \mathrm{L}$ using $10 \mathrm{ng}$ of DNA template, 0.10-015 $\mu \mathrm{M}$ of each primer, and 1X PCR Master mix from the QIAGEN multiplex PCR kit (Qiagen, Hilden, Germany). The PCR cycling conditions for the three multiplexes were as follows: pre-incubation for $15 \mathrm{~min}$ at $95^{\circ} \mathrm{C}$, followed by five (sets A and B) or seven (set C) touchdown cycles at $95^{\circ} \mathrm{C}$ for $30 \mathrm{~s}$, 65- ${ }^{\circ} \mathrm{C} /$ cycle for $1 \mathrm{~min}$ and $72{ }^{\circ} \mathrm{C}$ for $1 \mathrm{~min}$, followed by 30 cycles at $95^{\circ} \mathrm{C}$ for $30 \mathrm{~s}, 60^{\circ} \mathrm{C}$ (set $\mathrm{A}$ and B) or $58^{\circ} \mathrm{C}$ (set $\mathrm{C}$ ) for $1 \mathrm{~min}, 72^{\circ} \mathrm{C}$ for $1 \mathrm{~min}$ and the ending cycle $30 \mathrm{~min}$ extension at $72^{\circ} \mathrm{C}$. To evaluate the amplification results, $1 \mu \mathrm{L}$ of the PCR product was separated by electrophoresis on a $2 \%$ agarose gel. The amplification bands were detected using the GelDoc 2000 (Bio-Rad Laboratories, Hercules, CA, USA) transilluminator and visualized with the Quantity One Analysis Software (Bio-Rad Laboratories, Hercules, CA, USA). Then, the diluted products mixed with formamide were analyzed on ABI PRISM DNA sequencer (3130XL; Applied Biosystems, Foster City, CA, USA). The GeneScan 500 LIZ Size standard was used to determine allele size. Fragment analysis and sizing were carried out using the Peak Scanner Software version 1.0 (Applied Biosystems).

\subsection{Physical Parameters}

For each clone, 20 fruits were taken from the 60 collected and the following physical parameters were measured: fruit weight (FW) (g), equatorial diameter 1 (D1) (mm), equatorial diameter 2 (D2) $(\mathrm{mm})$, average equatorial diameter $(\mathrm{AD}=(\mathrm{D} 1+\mathrm{D} 2) / 2)(\mathrm{mm})$, fruit height $1(\mathrm{H} 1)(\mathrm{mm})$, fruit height $2(\mathrm{H} 2)(\mathrm{mm})$, average fruit height $(\mathrm{Am}=(\mathrm{H} 1 / \mathrm{H} 2) / 2)(\mathrm{mm})$, width of the pedicle cavity $(\mathrm{PCw})(\mathrm{mm})$, depth of the pedicle cavity (PCd) (mm), width of the calycine cavity $(\mathrm{CCw})(\mathrm{mm})$, depth of the calyx cavity (CCd) (mm), aperture of locules (in transverse section) (OL) [37], number of viable seeds (Sv), number of abortive seeds (Sa), and firmness $(\mathrm{F})\left(\mathrm{kg} \mathrm{cm}^{-2}\right)$.

Fruit weight was measured with a Sartorius digital bench scale (model BL-600, $0.01 \mathrm{~g}$ accuracy). Fruit equatorial diameter, length, and depth of the pedicle cavity and the width and depth of the calycine cavity were measured with a Mitutoyo CD-15DC Digimatic caliper (0.01 $\mathrm{mm}$ accuracy). Pulp firmness was assessed with a Bertuzzi penetrometer (model FT 327, with an $8 \mathrm{~mm}$ deep probe). Apple peel color (four different measurements at four equidistant points on the equatorial region of each fruit) was assessed using a Minolta C-300 Chroma Meter (Minolta Corp., Osaka, Japan) coupled to a Minolta DP-301 data processor, and the results were expressed in the CIELab system. The mean values for lightness $\left(\mathrm{L}^{*}\right)$, red-greenness $\left(\mathrm{a}^{*}\right)$, and blue-yellowness $\left(\mathrm{b}^{*}\right)$ coordinates for each fruit were reported. In addition, the objective color was calculated as chromaticity or chroma $\left[\mathrm{C}^{*}=\left(\mathrm{a}^{* 2}+\mathrm{b}^{* 2}\right)^{1 / 2}\right]$ and hue angle $\left[\mathrm{H}^{\mathrm{o}}=\arctan \right.$ $\left(\mathrm{b}^{*} / \mathrm{a} *\right)$. For the moisture content, samples were dried at $60{ }^{\circ} \mathrm{C}$ for $48 \mathrm{~h}$ until a constant weight was reached [38]. 


\subsection{Total Soluble Solids, Acidity, and Maturity Index}

Total soluble solids (TSS) were assessed in triplicate with a digital refractometer Atago N1 (Atago Co. Ltd., Tokyo, Japan) at $20{ }^{\circ} \mathrm{C}$, and expressed as ${ }^{\circ}$ Brix. Total titratable acidity (TA) was determined in triplicate using an automatic titration device (877 Titrino plus, Metrohm ion analyses CH9101, Herisau, Switzerland) with $0.1 \mathrm{~N} \mathrm{NaOH}$ up to $\mathrm{pH} 8.1$, using $1 \mathrm{~mL}$ diluted juice in $25 \mathrm{~mL}$ distilled $\mathrm{H}_{2} \mathrm{O}$, and the results expressed as g malic acid $\mathrm{L}^{-1}$. Once the TSS and TA contents were assessed, the maturity index (MI) of the evaluated varieties was determined (TSS/TA).

\subsection{Antioxidant Activities (AA) and Total Polyphenol Content (TPC)}

There are different methods for evaluating fruit antioxidant activity. This diversity of methods is because none of them are able to exactly determine the total antioxidant potential in a food system by themselves. For this reason, the antioxidant activity of apple fruits was evaluated using three different assays: (i) the free radical scavenging activity was tested using $\mathrm{ABTS}^{+}$and $\mathrm{DPPH}^{\bullet}$ assays and (ii) the ferric reducing ability (FRAP assay). The $\mathrm{ABTS}^{+}$(2, 2-azinobis-(3-ethylbenzothiazoline-6-sulfonic acid)) radical cation and ferric-reducing antioxidant power (FRAP) methods were applied according to [39] and [40], respectively. The radical scavenging activity was evaluated using the $\mathrm{DPPH}^{\bullet}$ radical (2, 2-diphenyl-1-picrylhydrazyl) method, as described by [41] with a modification in the reaction time [42]. Calibration curves, in the $0.5-5.0 \mathrm{mmol}$ Trolox $\mathrm{L}^{-1}$ range, were prepared for all three methods and showed good linearity $\left(R^{2}=0.998\right)$. Results were expressed as mmoles Trolox $\mathrm{kg}^{-1}$ fresh weight (fw).

The TPC was measured using the Folin-Ciocalteu colorimetric method described by Singleton et al. [43]. The absorbance of the resulting blue color was measured at $765 \mathrm{~nm}$ using a UV-visible spectrophotometer (Termospectromic Helios Gamma UVG 1002 E, Cambridge, UK). Calibration curves with concentrations of gallic acid as the standard were used for quantification. All determinations were performed in triplicate and the results were expressed as gallic acid equivalents (GAE) in, $\mathrm{mg} 100 \mathrm{~g}^{-1} \mathrm{fw}$.

\subsection{Sugar Profile}

Sugar profiles were obtained following the method described by Hernández et al. [44] using HPLC, with some modifications. The extraction consisted in the homogenization of $1 \mathrm{~mL}$ of sample juice with $5 \mathrm{~mL}$ of phosphate buffer followed by filtration and injection. A column (Supelcogel TM C-610H column $30 \mathrm{~cm} \times 7.8 \mathrm{~mm}$ ) and a pre-column (Supelguard $5 \mathrm{~cm} \times 4.6 \mathrm{~mm}$, Supelco, Inc., Bellefonte, PA, USA) were used for the analysis. Sugars were detected using a refractive index detector (RID).

Sugars from Sigma (Poole, Dorset, UK) were used for calibration curves and quantification and showed good linearity $\left(R^{2} \geq 0.999\right)$. Analyses were run in triplicate and results were expressed as \%.

\subsection{Sensory Evaluation}

Seven trained panelists (aged 40-60 years; four female and three male) with more than $500 \mathrm{~h}$ of training in sensory testing from the Department of Agrofood Technology (UMH) participated in this study. The study was conducted in a normalized tasting room of UMH $\left(21 \pm 2{ }^{\circ} \mathrm{C}\right.$ and $55 \% \pm 5 \%$ relative humidity) with 15 normalized sensory cabins. Samples were randomly served into odor-free, disposable $90 \mathrm{~mL}$ covered plastic cups, at room temperature, and coded using 3-digit numbers. Unsalted crackers and distilled water were provided to panelists to clean their palates between samples.

Each panelist filled a questionnaire evaluating the following attributes: color (peel color, pulp color, homogeneity of peel color), flavor ((apple, fruity, pineapple, quince, and pear odor (perception of volatile compounds with the fruit outside the mouth), sourness, sweetness, bitterness, astringency and fruity, apple, pineapple, and apple-pear aroma (perception of volatile compounds with the fruit outside 
the mouth), aftertaste) and texture (hardness, crispness, juiciness, crispy, granularity, fibrousness). The attributes description and the reference materials used are shown in Table 2.

Table 2. List of appearance, flavor, and texture attributes used to describe apple fruits and their definitions.

\begin{tabular}{|c|c|c|}
\hline Attribute & Definition & References \\
\hline Peel color & Color of the fruit peel & $0=$ green, $10=$ yellow, $20=$ red \\
\hline Pulp color & Color of the fruit pulp & $0=$ green, $10=$ yellow \\
\hline Homogeneity Peel color & Homogeneity of color in the fruit peel & $0=$ none, $10=$ very strong \\
\hline Apple smell & \multirow{5}{*}{$\begin{array}{c}\text { Sweet. Light fruity. Somewhat floral aromatic, associated with } \\
\text { apple juice and apples } \\
\text { Fresh. Fruity aromatics associated with undefined fruits } \\
\text { Sour. Fresh, fruity aromatics associated with ripe pineapple } \\
\text { Floral. Fresh and fruity aromatics associated with quince } \\
\text { Sweet. Slightly musty. Floral. Honey/caramel-like. Fruity aromatic } \\
\text { associated with ripe pears }\end{array}$} & Hacendado $*$ mango-apple nectar $=5.5$ \\
\hline Fruity smell & & Hacendado * yoghurt "Macedonia" $=8.5$ \\
\hline Pineapple smell & & Hacendado $* 100 \%$ pineapple juice $=7.5$ \\
\hline Quince smell & & Freshly harvested quinces. cv. Vranja $=6.5$ \\
\hline Pear smell & & Hacendado $*$ pear nectar $=6.5$ \\
\hline Sourness & Fundamental taste factor of which citric acid is typical & $0.05 \%$ Citric acid solution $=3.5$ \\
\hline Sweetness & Fundamental taste factor of which sucrose is typical & $2 \%$ Sucrose solution $=2.0$ \\
\hline Bitterness & Fundamental taste factor of which caffeine or quinine is typical & $0.020 \%$ Caffeine solution $=3.5$ \\
\hline Astringency & Dry puckering mouthfeel associated with an alum solution & $0.05 \%$ Alum solution $=2.5$ \\
\hline Fruity flavor & A flavor blend which is sweet and reminiscent of a variety of fruits & $0=$ none, $10=$ very strong \\
\hline Apple flavor & A flavor commonly associated with apple juice and apples & $0=$ none, $10=$ very strong \\
\hline Pineapple Flavor & A flavor commonly associated with pineapple juice and pineapples & $0=$ none, $10=$ very strong \\
\hline Apple-Pear Flavor & Flavor reminiscent of a variety of different apples and pears & $0=$ none, $10=$ very strong \\
\hline Aftertaste & Remaining desirable flavor after swallowing & $5 \mathrm{~s}=1,20 \mathrm{~s}=10$ \\
\hline Hardness & Force required to bite through & Fresh unpeeled carrot $=8.5$ \\
\hline Crunchiness & The intensity of audible noise at first chew with molars & Fresh unpeeled carrot $=7.5$ \\
\hline Juiciness & Amount of water released from the sample during chewing & Raw peeled carrot $=1.5$ \\
\hline Corkiness & Puffiness of the cross-section & Marshmallow $=1.0$ \\
\hline Graininess & $\begin{array}{l}\text { Amount of woody particles remaining in the mouth just before } \\
\text { swallowing the sample }\end{array}$ & Over-ripe pear. cv. Alejandrina $=6.0$ \\
\hline Fibrosity & Stringy particles (size and amount) & Fresh strawberry $=3.0$ \\
\hline
\end{tabular}

* Spanish commercial mark.

The panelists used a numerical scale from 0 to 10 with increments of 0.5 points, to rate the attribute's intensity, where 0 represented "no intensity" or "no perceptible intensity" and 10 "extremely strong". Spanish trained panels commonly use this scale because it is intuitive and very easy to understand. A different scale was used only for the "peel color" attribute, with a numeric scale from 0 to 20 , where 0 represents green, 10 represents yellow, and 20 represents red.

\subsection{Statistical Analysis}

The results were analyzed using the SPSS v.22.0 statistical program for Windows (SPSS Science, Chicago, IL, USA). The differences among varieties $(p<0.05)$ were evaluated with an analysis of variance (ANOVA). The method used to discriminate among means (Multiple Range Test) was Tukey's test $(p<0.05)$, and all the results were shown as mean values \pm SE (standard error). Principal component analysis (PCA) and cluster analysis (CA) were also performed. The cluster analysis was applied to standardized data for hierarchical associations, employing Ward's method for agglomeration and the squared Euclidean distance as the dissimilarity measure.

\section{Results and Discussion}

\subsection{Molecular Characterization}

The five clones of "Pero de Cehegín" shared the same SSR profile at the 13 microsatellite markers studied. The size of the 26 alleles obtained for "Pero de Cehegín" (clone 1), "Fuji", and "Granny Smith" (references varieties) are shown in Table 3. The two reference varieties were used for size alignment and comparison with other studies. 
Table 3. Molecular profiles (allele sizes in base pairs) of "Pero de Cehegín" and two commercial varieties used as reference ("Fuji" and "Granny Smith") obtained with 13 microsatellite markers.

\begin{tabular}{|c|c|c|c|c|c|c|c|c|c|c|c|c|c|}
\hline \multicolumn{14}{|c|}{ Locus } \\
\hline & $\mathrm{CH}_{01 \mathrm{f} 02^{\mathrm{b}}}$ & CH01h01 b & $\mathrm{CH}_{0} 01 \mathrm{~h} 10^{\mathrm{b}}$ & $\mathrm{CH} 02{\mathrm{c} 09^{\mathrm{b}}}$ & $\mathrm{CH} 02 \mathrm{c} 11^{\mathrm{b}}$ & $\mathrm{CH} 02 \mathrm{~d} 08^{\mathrm{b}}$ & $\mathrm{CH}^{2} 03 \mathrm{~d} 07^{\mathrm{b}}$ & $\mathrm{CH}^{2} 4 \mathrm{c} 07^{\mathrm{b}}$ & $\mathrm{CH}_{04 \mathrm{e} 05^{\mathrm{b}}}$ & $\mathrm{CH}^{2} 05 \mathrm{f} 06^{\mathrm{b}}$ & GD12a & GD147a & $\mathrm{Hi} 02 \mathrm{c} 07^{\mathrm{c}}$ \\
\hline Reference & & & & & & & & & & & & & \\
\hline Fuji AD 3488 * & 182 & 116 & 91/97 & $231 / 243$ & $230 / 234$ & 211 & 227 & $106 / 118$ & $175 / 202$ & $164 / 174$ & $148 / 154$ & $139 / 153$ & $116 / 116$ \\
\hline $\begin{array}{c}\text { Granny Smith AD } 3196 * \\
\text { Accession }\end{array}$ & $180 / 206$ & $112 / 130$ & 97 & $231 / 241$ & $228 / 232$ & $211 / 250$ & $193 / 227$ & $106 / 112$ & 175 & $170 / 174$ & $150 / 154$ & $133 / 139$ & $114 / 118$ \\
\hline Pero de Cehegín (P1)* & $168 / 182$ & $112 / 118$ & $101 / 119$ & $251 / 255$ & $210 / 224$ & $211 / 254$ & $193 / 193$ & 98/108 & $175 / 203$ & $174 / 180$ & $133 / 153$ & $152 / 152$ & $114 / 116$ \\
\hline
\end{tabular}

${ }^{\mathrm{a}}[45],{ }^{\mathrm{b}}[46],{ }^{\mathrm{c}}[47],{ }^{*}$ Alleles sizes were aligned as profiles published in Germplasm Bank at the University of Lleida [48] 
To our knowledge, this is the first molecular study for the identification of the "Pero de Cehegín". The profile of "Pero de Cehegín", did not show correspondence with profiles of diploid accessions named "Pero" in other Iberian collections conserved at different institutions. No correspondence was found with "Pero Rufino", "Pero Rosa", and other "Pero" accessions from local and traditional apples located in Andalucía [19], "Peruco Lardero" from the germplasm bank at the University of Lleida [48] and its synonym "Pero Mingan" at Aula Dei-CSIC [36], "Pero de Coura", and other "Pero" from three Portuguese germplasm banks [49]. Additionally, correspondence was neither found with other triploid accessions such as "Pero Pardo", "Pera de Sangüesa" (syn. Moceta) at Aula Dei-CSIC, all characterized in larger studies including 498 and 1453 accessions [23] from Spanish apple germplasms. Therefore, this is the first molecular study that identifies "Pero de Cehegín" as a new genotype, not present in other Spanish germplasm banks.

\subsection{Physical Parameters}

Table 4 shows the results obtained for the physical evaluation of five "Pero de Cehegín" clones studied. Important variability was found for fruit weight, diameter, and height among the different "Pero de Cehegín" clones. The smallest fruits were those produced by the P3 clone with a FW $=148.41 \mathrm{~g}$, which was not significantly different with "Golden Delicious", while the P2 clone, with a mean weight of $219.43 \mathrm{~g}$, had the largest fruits. The rest of the clones and "Fuji" apples had intermediate values.

As for the AD, we found two groups. Group 1, with the higher values, included two "Pero de Cehegín" clones (P1, P2) and "Fuji" and group 2, with lower values, included the rest of clones and "Golden Delicious". For the average height (AH) of the fruit, the P2 clone had the highest value (81.77 $\mathrm{mm})$, and P3 (68.33 mm), "Fuji" (68.25 mm), and "Golden Delicious" (64.23 mm) with the lowest values. These results highlight the morphometric differences shown by "Pero de Cehegín" as compared to common commercial varieties such as "Fuji" and "Golden Delicious".

Fruit size plays an important role in consumer preferences when buying fruit because different fruit sizes can satisfy different types of consumers [33]. The literature has reported varieties with an average fruit weight above $300 \mathrm{~g}$ [50] but also values below $100 \mathrm{~g}$ [31]. The present results show that the "Pero de Cehegín" clones have an adequate size for commercialization, with values even higher than "Fuji" and "Golden Delicious" varieties, which are widely accepted by consumers. In general, large fruits are preferred by most consumers, but for fresh consumption, only up to a certain size limit [51,52]. Hampson et al. [53] indicated that for the dessert apples, the ideal size was between 74 and $76 \mathrm{~mm}$ in diameter. In the "Pero de Cehegín" clones studied the average diameter of the fruit ranged between $66(\mathrm{P} 3)$ and $75 \mathrm{~mm}(\mathrm{P} 2)$, which agrees with the range of acceptance.

On the other hand, the PCw of the "Pero de Cehegín" P3 clone $(27.86 \mathrm{~mm})$ has a lower value than the rest of the clones (between 30.53 and $31.11 \mathrm{~mm}$ ), similar to "Fuji" $(28.69 \mathrm{~mm}$ ) and "Golden Delicious" $(27.15 \mathrm{~mm})$. The PCd values oscillated between 14.68 and $17.16 \mathrm{~mm}$, with significant differences only between the P1 and P5 clones but without differences observed with commercial varieties. The CCw varied between 25.30 and $29.89 \mathrm{~mm}$. Only clones P3, P4, and P5 were non-significant with "Fuji" and "Golden Delicious". The calicine depth (CCd) varied between 12.48 and $15.91 \mathrm{~mm}$, and it was only significantly different between P2 and P3 clones.

For the locule opening characteristic (in a cross-section) (OL) [37], all the studied samples had a level 2 without significant differences among them. 
Table 4. Mean values of the morphological parameters measured in five clones of "Pero de Cehegín" and two varieties of reference ("Fuji" and "Golden Delicious") harvested in 2017.

\begin{tabular}{|c|c|c|c|c|c|c|c|}
\hline \multirow{2}{*}{ Parameters } & \multicolumn{5}{|c|}{ "Pero de Cehegín" } & \multicolumn{2}{|c|}{ Commercial Varieties } \\
\hline & P1 & P2 & P3 & P4 & P5 & Fuji & Golden Delicious \\
\hline FW (g) & $195.18 \pm 4.14 \mathrm{c}$ & $219.43 \pm 8.20 \mathrm{~d}$ & $148.41 \pm 3.52 \mathrm{a}$ & $170.75 \pm 4.12 \mathrm{~b}$ & $181.39 \pm 4.70 \mathrm{bc}$ & $190.79 \pm 4.25 \mathrm{bc}$ & $149.68 \pm 2.78 \mathrm{a}$ \\
\hline $\mathrm{AD}(\mathrm{mm})$ & $72.80 \pm 0.62 \mathrm{bcd}$ & $75.43 \pm 1.10 \mathrm{~d}$ & $66.24 \pm 0.57 a$ & $69.86 \pm 0.71 \mathrm{ab}$ & $70.85 \pm 0.71 \mathrm{abc}$ & $72.94 \pm 0.67 \mathrm{~cd}$ & $68.02 \pm 0.45 \mathrm{ab}$ \\
\hline $\mathrm{AH}(\mathrm{mm})$ & $77.40 \pm 0.91 \mathrm{~d}$ & $81.77 \pm 1.32 \mathrm{e}$ & $68.33 \pm 0.86 \mathrm{~b}$ & $73.48 \pm 0.64 \mathrm{c}$ & $75.19 \pm 0.93 \mathrm{~cd}$ & $68.25 \pm 0.91 \mathrm{~b}$ & $64.23 \pm 0.73 \mathrm{a}$ \\
\hline $\mathrm{PCw}(\mathrm{mm})$ & $30.53 \pm 0.33 b$ & $31.39 \pm 0.48 \mathrm{~b}$ & $27.86 \pm 0.38 \mathrm{a}$ & $31.11 \pm 0.46 \mathrm{~b}$ & $30.62 \pm 0.37 b$ & $28.69 \pm 0.44 a$ & $27.15 \pm 0.37 a$ \\
\hline PCd (mm) & $14.68 \pm 0.99 \mathrm{a}$ & $14.94 \pm 0.55 \mathrm{ab}$ & $15.65 \pm 0.53 \mathrm{ab}$ & $15.74 \pm 0.44 \mathrm{ab}$ & $17.16 \pm 0.55 \mathrm{~b}$ & $14.98 \pm 0.40 \mathrm{ab}$ & $15.77 \pm 0.35 \mathrm{ab}$ \\
\hline $\mathrm{CCw}(\mathrm{mm})$ & $29.89 \pm 0.68 c$ & $27.77 \pm 0.47 \mathrm{bc}$ & $25.77 \pm 0.38 \mathrm{ab}$ & $25.72 \pm 0.44 \mathrm{ab}$ & $26.67 \pm 0.36 \mathrm{ab}$ & $27.64 \pm 0.68 \mathrm{~b}$ & $25.30 \pm 0.45 \mathrm{a}$ \\
\hline $\mathrm{CCd}(\mathrm{mm})$ & $14.02 \pm 0.60 \mathrm{ab}$ & $15.91 \pm 0.67 b$ & $12.87 \pm 0.37 a$ & $14.15 \pm 0.40 \mathrm{ab}$ & $13.58 \pm 0.63 \mathrm{ab}$ & $12.48 \pm 0.68 \mathrm{a}$ & $13.61 \pm 0.67 \mathrm{ab}$ \\
\hline $\mathrm{Sv}$ & $1.40 \pm 0.43 \mathrm{a}$ & $1.85 \pm 0.59 \mathrm{ab}$ & $1.05 \pm 0.47 \mathrm{a}$ & $1.45 \pm 0.43 \mathrm{a}$ & $2.65 \pm 0.40 \mathrm{ab}$ & $2.00 \pm 0.63 \mathrm{ab}$ & $3.75 \pm 0.64 b$ \\
\hline $\mathrm{Sa}$ & $3.40 \pm 0.64 \mathrm{~cd}$ & $1.00 \pm 0.46 \mathrm{ab}$ & $0.80 \pm 0.41 \mathrm{a}$ & $4.15 \pm 0.46 \mathrm{~d}$ & $2.95 \pm 0.48 \mathrm{bcd}$ & $2.20 \pm 0.46 \mathrm{abcd}$ & $1.80 \pm 0.36 \mathrm{abc}$ \\
\hline OL & $2.00 \pm 0.01$ & $2.00 \pm 0.02$ & $2.00 \pm 0.01$ & $2.00 \pm 0.03$ & $2.00 \pm 0.01$ & $2.00 \pm 0.01$ & $2.00 \pm 0.01$ \\
\hline $\mathrm{F}\left(\mathrm{kg} \mathrm{cm}^{-2}\right)$ & $3.65 \pm 0.05 \mathrm{~b}$ & $3.96 \pm 0.08 c$ & $4.44 \pm 0.10 \mathrm{~d}$ & $4.00 \pm 0.06 c$ & $3.93 \pm 0.05 \mathrm{bc}$ & $2.61 \pm 0.07 \mathrm{a}$ & $2.65 \pm 0.07 \mathrm{a}$ \\
\hline Moisture content (\%) & $79.72 \pm 1.27 \mathrm{ab}$ & $79.76 \pm 0.67 \mathrm{ab}$ & $78.24 \pm 0.93 \mathrm{a}$ & $78.45 \pm 1.09 \mathrm{ab}$ & $77.92 \pm 0.82 \mathrm{a}$ & $78.85 \pm 0.28 \mathrm{ab}$ & $82.53 \pm 0.61 \mathrm{~b}$ \\
\hline
\end{tabular}

Values (means \pm SE $n=3$ ) followed by the same letter, within the same file, are not significantly different according to Tukey's test procedure at $5 \%$ significance level: Abbreviations: FW: fruit weight; AD: average equatorial diameter; AH: average fruit height; PCw: width of the pedicle cavity; PCd: depth of the pedicle cavity; CCw: width of the calycine cavity; CCd: depth of the calyx cavity; Sv: number of viable seeds; Sa: number of abortive seeds; OL: aperture of locules; F: firmness. 
The number of viable seeds (Sv) for "Pero de Cehegín" clones were similar (average values between 1.05 units for P3 and 2.65 units for P5). The maximum Sv value was found for the "Golden Delicious" variety (3.75). More variability was found for abortive seeds (Sa), with mean values ranging from 0.8 units (P3) to 4.15 units (P4).

Fruit firmness in "Pero de Cehegín" clones had higher values than those of the commercial varieties, ranging from 3.65 (P1) to $4.44 \mathrm{~kg} \mathrm{~cm}^{-2}$ (P3). Firmness is one of the most important parameters perceived by consumers [54], as a high fruit firmness is often related to freshness, while fruit flouriness can be a deterrent to the increase in fresh fruit consumption [55]. Therefore, the firmness found in "Pero de Cehegín" is a positive characteristic that may help with its consumption. Firmness, juiciness, and no flouriness are the textural features preferred by consumers [56].

For moisture content, all the clones showed similar values ranging from $77.92 \%$ (P5) to $79.72 \%$ (P1). The "Fuji" variety had a value of $78.85 \%$ and the highest value was observed for the "Golden Delicious" variety $(82.53 \%)$. In the literature, different varieties have been reported with values between $78.12 \%$ and $95.00 \%[27,29,57,58]$. The low moisture content for "Pero de Cehegín" could be directly related to their good natural properties for conservation.

Similarly, the color directly affects the appearance and the acceptability of the fruit by the consumer [29]. The green, yellow, and red apple peel colors can help to distinguish the cultivar [33]. Therefore, color can be considered one of the most important fruit characteristics, aside from being one of the indicators of maturity.

The color parameters for the different studied clones are shown in Table 5. For all color traits, "Fuji" was significantly different to "Pero de Cehegín" clones and the "Golden Delicious" variety. For all the parameters, except $\mathrm{L}^{*}$ and a *, all the "Pero de Cehegín" clones were not significantly different. For luminosity $\left(\mathrm{L}^{*}\right)$, the results indicated that the peel of "Pero de Cehegín" fruits had light colors. Four clones (P1, P2, P3, and P4) were not significantly different amongst themselves. The "Fuji" variety (bicolor apple) showed the lowest luminosity and the "Golden Delicious" variety was the most luminous fruit, although no significant differences between P2, P3, and P5 "Pero de Cehegín" clones were observed. The results of the $\mathrm{a}$ * index, which represents the red-green color scale, showed small differences among the "Pero de Cehegín" clones and Golden Delicious. As expected, only Fuji showed a high value of the colorimetric variable a * $(24.52$, reddish color).

\subsection{Total Soluble Solids, Acidity, and Maturity Index}

"Pero de Cehegín" did not show significant differences among clones for any of the traits evaluated (Table 6). However, among commercial varieties ("Fuji" and "Golden Delicious") differences were also found in TSS and TA. These differences could be due to the genetic variation among the plant material studied since based on the literature, the composition of apple fruits will be affected by the genotype [25,59]. 
Table 5. Color coordinates (CIEL * $\left.\mathrm{a}^{*} \mathrm{~b}^{*}\right)$ in the five clones of "Pero de Cehegín" and varieties of reference ("Fuji" and "Golden Delicious") harvested in 2017.

\begin{tabular}{|c|c|c|c|c|c|c|c|}
\hline \multirow{2}{*}{ Parameters } & \multicolumn{5}{|c|}{ "Pero de Cehegín" } & \multicolumn{2}{|c|}{ Commercial Varieties } \\
\hline & P1 & P2 & P3 & $\mathbf{P 4}$ & P5 & Fuji & Golden Delicious \\
\hline$L^{*}$ & $72.84 \pm 0.45 b$ & $74.18 \pm 0.50 \mathrm{bc}$ & $74.76 \pm 0.39 \mathrm{bc}$ & $72.73 \pm 0.58 b$ & $75.70 \pm 0.54 c$ & $51.57 \pm 0.95 \mathrm{a}$ & $76.09 \pm 0.29 c$ \\
\hline$a^{*}$ & $-4.87 \pm 0.40 \mathrm{a}$ & $-3.71 \pm 0.42 \mathrm{ab}$ & $-2.93 \pm 0.42 \mathrm{abc}$ & $-4.84 \pm 0.35 \mathrm{ab}$ & $-2.81 \pm 0.52 b c$ & $24.52 \pm 0.81 \mathrm{~d}$ & $-1.03 \pm 0.28 c$ \\
\hline$b^{*}$ & $42.31 \pm 0.52 b$ & $44.09 \pm 0.66 \mathrm{bc}$ & $44.39 \pm 0.52 \mathrm{bc}$ & $43.51 \pm 0.63 \mathrm{bc}$ & $43.13 \pm 0.60 \mathrm{~b}$ & $18.31 \pm 0.66 \mathrm{a}$ & $45.95 \pm 0.47 c$ \\
\hline$C^{*}$ & $42.67 \pm 0.49 b$ & $44.34 \pm 0.64 \mathrm{bc}$ & $44.58 \pm 0.51 \mathrm{bc}$ & $43.84 \pm 0.60 \mathrm{bc}$ & $43.35 \pm 0.58 \mathrm{~b}$ & $31.16 \pm 0.45 a$ & $46.00 \pm 0.47 c$ \\
\hline $\mathrm{H}^{\mathrm{o}}$ & $96.72 \pm 0.56 c$ & $95.06 \pm 0.58 c$ & $93.96 \pm 0.56 \mathrm{bc}$ & $96.54 \pm 0.51 c$ & $93.95 \pm 0.71 b c$ & $37.15 \pm 1.75 a$ & $91.34 \pm 0.36 b$ \\
\hline
\end{tabular}

Values (means \pm SE of $n=3$ ) followed by the same letter, within the same file, are not significantly different according to Tukey's test procedure at $5 \%$ significance level.

Table 6. Quality parameters, antioxidant activity, contents of total phenolic and sugars in the five clones of "Pero de Cehegín" and varieties of reference ("Fuji" and “Golden Delicious") harvested in 2017.

\begin{tabular}{|c|c|c|c|c|c|c|c|}
\hline \multirow{2}{*}{ Parameters } & \multicolumn{5}{|c|}{ “Pero de Cehegín” Clones } & \multicolumn{2}{|c|}{ Commercial Varieties } \\
\hline & P1 & P2 & P3 & P4 & P5 & Fuji & Golden Delicious \\
\hline Total soluble solids $\left({ }^{\circ}\right.$ Brix $)$ & $15.70 \pm 0.38 \mathrm{ab}$ & $17.10 \pm 0.21 \mathrm{~b}$ & $17.20 \pm 0.17 \mathrm{~b}$ & $15.90 \pm 0.50 \mathrm{~b}$ & $15.40 \pm 0.12 \mathrm{ab}$ & $16.63 \pm 0.65 b$ & $13.90 \pm 0.40 \mathrm{a}$ \\
\hline Total acidity ( $\mathrm{g}$ of malic acid $\mathrm{L}^{-1}$ ) & $1.70 \pm 0.04 \mathrm{a}$ & $1.72 \pm 0.11 \mathrm{a}$ & $1.44 \pm 0.16 \mathrm{a}$ & $1.83 \pm 0.06 \mathrm{a}$ & $1.68 \pm 0.22 \mathrm{a}$ & $3.97 \pm 0.34 \mathrm{~b}$ & $3.30 \pm 0.22 b$ \\
\hline Maturity index & $92.41 \pm 2.2 \mathrm{~b}$ & $100.10 \pm 5.51 \mathrm{~b}$ & $122.30 \pm 13.88 \mathrm{~b}$ & $86.98 \pm 4.62 \mathrm{~b}$ & $94.56 \pm 11.90 \mathrm{~b}$ & $42.21 \pm 2.10 \mathrm{a}$ & $42.47 \pm 2.95 \mathrm{a}$ \\
\hline $\mathrm{ABTS}^{+}\left(\mathrm{mmol}\right.$ Trolox kg $\left.{ }^{-1} \mathrm{fw}\right)$ & $1.95 \pm 0.33 \mathrm{a}$ & $1.48 \pm 0.03 \mathrm{a}$ & $1.46 \pm 0.25 \mathrm{a}$ & $1.67 \pm 0.11 \mathrm{a}$ & $1.76 \pm 0.22 \mathrm{a}$ & $1.08 \pm 0.37 \mathrm{a}$ & $0.86 \pm 0.54 \mathrm{a}$ \\
\hline 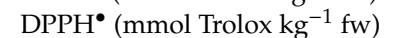 & $2.83 \pm 0.17 \mathrm{a}$ & $2.51 \pm 0.31 \mathrm{a}$ & $2.88 \pm 0.33 \mathrm{a}$ & $3.20 \pm 0.23 \mathrm{a}$ & $3.22 \pm 0.17 \mathrm{a}$ & $2.89 \pm 0.08 \mathrm{a}$ & $2.58 \pm 0.43 \mathrm{a}$ \\
\hline FRAP (mmol Trolox $\left.\mathrm{kg}^{-1} \mathrm{fw}\right)$ & $0.66 \pm 0.06 \mathrm{bc}$ & $0.52 \pm 0.06 \mathrm{abc}$ & $0.60 \pm 0.03 \mathrm{abc}$ & $0.41 \pm 0.00 \mathrm{abc}$ & $0.69 \pm 0.08 \mathrm{c}$ & $0.32 \pm 0.10 \mathrm{ab}$ & $0.25 \pm 0.13 a$ \\
\hline TPC (mg GAE $\left.100 \mathrm{~g}^{-1} \mathrm{fw}\right)$ & $199.44 \pm 38.05 \mathrm{ab}$ & $180.66 \pm 0.62 \mathrm{ab}$ & $197.56 \pm 13.90 \mathrm{ab}$ & $117.04 \pm 20.38 \mathrm{ab}$ & $157.18 \pm 20.80 \mathrm{ab}$ & $102.72 \pm 38.60 \mathrm{a}$ & $282.07 \pm 71.71 \mathrm{~b}$ \\
\hline Sucrose $\left(\mathrm{g} 100 \mathrm{~mL}^{-1}\right)$ & $6.58 \pm 0.1 \mathrm{~b}$ & $7.24 \pm 0.13 b$ & $6.61 \pm 0.66 \mathrm{~b}$ & $6.99 \pm 0.20 \mathrm{~b}$ & $5.85 \pm 0.07 \mathrm{~b}$ & $3.96 \pm 0.17 \mathrm{a}$ & $3.17 \pm 0.21 \mathrm{a}$ \\
\hline Glucose ( $\left.100 \mathrm{~mL}^{-1}\right)$ & $2.54 \pm 0.22 \mathrm{a}$ & $2.50 \pm 0.23 \mathrm{a}$ & $2.58 \pm 0.26 \mathrm{a}$ & $2.00 \pm 0.33 \mathrm{a}$ & $2.53 \pm 0.07 \mathrm{a}$ & $3.32 \pm 0.48 \mathrm{a}$ & $2.35 \pm 0.15 \mathrm{a}$ \\
\hline Fructose $\left(\mathrm{g} 100 \mathrm{~mL}^{-1}\right)$ & $6.52 \pm 0.20 \mathrm{a}$ & $6.43 \pm 0.20 \mathrm{a}$ & $5.93 \pm 0.36 \mathrm{a}$ & $5.59 \pm 0.22 \mathrm{a}$ & $5.88 \pm 0.01 \mathrm{a}$ & $8.85 \pm 0.10 b$ & $8.40 \pm 0.48 b$ \\
\hline
\end{tabular}

Values (means \pm SE of $n=3$ ) followed by the same letter, within the same row are not significantly different according to Tukey's test procedure at $5 \%$ significance level. Abbreviations: TPC: total phenolic; GAE: gallic acid equivalents; fw: fresh weight. 
The total soluble solids (TSS) parameter varied from $15.40^{\circ}$ Brix for the P5 clone up to $17.20^{\circ}$ Brix for the P3 clone, without significant differences with the rest of the clones and "Fuji" (16.63 $\left.{ }^{\circ} \mathrm{Brix}\right)$. Clones P1 and P5 were not different from "Golden Delicious" (13.9 ${ }^{\circ}$ Brix). Previous studies on different varieties have reported values between 9.99 and $18.1^{\circ}$ Brix $[25,27-29,60]$.

The total acidity (TA) mean values for the different "Pero de Cehegín" clones ranged from 1.44 (P3) to $1.83 \mathrm{~g} \mathrm{~L}^{-1}$ (P4) without significant differences between them, but these values were significantly lower than in the "Fuji" and "Golden Delicious" varieties (3.97 and $3.30 \mathrm{~g} \mathrm{~L}^{-1}$, respectively). The total acidity value (TA) of the clone P3 of "Pero de Cehegín" was lower than reported in other studies of apple varieties $[25,28,29,60-62]$. For apples, the total acidity is a very important parameter for the quality of fruit and consumption, particularly in Europe [63]. Some research studies [52,64] have indicated that total acidity values below $3 \mathrm{mg} \mathrm{mL}^{-1}$ and above $10 \mathrm{mg} \mathrm{mL}^{-1}$ can be undesirable. This statement could be in contradiction with the results of this work, as the acidity value for the "Pero de Cehegín" clones resulted below $3 \mathrm{mg} \mathrm{mL}^{-1}$ and this traditional Spanish apple fruit has been historically considered as appealing and of high quality.

The maturity index (MI) for the "Pero de Cehegín" clones ranged from 86.98 (P4) to 122.30 (P3), significantly higher as compared with "Golden Delicious" (MI: 42.47) and "Fuji" (MI: 42.21) varieties. Generally, the maturity index is considered as responsible for the fruit's taste, thus, based on these results, it could be affirmed that the "Pero de Cehegín" clones are sweet tasting.

\subsection{Antioxidant Activities (AA) and Total Polyphenol Content (TPC)}

To evaluate the potential antioxidant activity of apple fruit, three in vitro assays, based on the scavenging activity $\left(\mathrm{DPPH}^{\bullet}\right)$, radical scavenging capacity $\left(\mathrm{ABTS}^{+}\right)$, and ferric reducing antioxidant potential (FRAP) were used and the results are reported in Table 6. The results did not indicate significant differences between "Pero de Cehegín" clones and commercial varieties ("Golden Delicious" and "Fuji") for $\mathrm{ABTS}^{+}$and DPPH" (Table 6). Differences were only obtained by using the FRAP method, with higher values for the "Pero de Cehegín" clones than for "Fuji" and "Golden Delicious" observed. A previous study [65] indicated the importance of the genotype in the antioxidant activity, and this could be reason for the differences observed.

In the present study, the highest TCP concentration was obtained by the "Golden Delicious" variety (282.07 mg GAE $100 \mathrm{~g}^{-1} \mathrm{fw}$ ). This value was significantly different when compared with the "Fuji" variety, which had the lowest TCP value (102.72 mg GAE $\left.100 \mathrm{~g}^{-1} \mathrm{fw}\right)$. However, the "Pero de Cehegín" clones did not show significant differences between them and the values for "Fuji" and

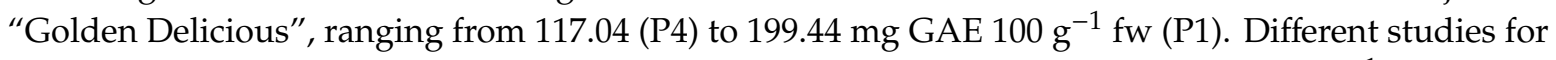
apple varieties have shown total polyphenol values between 66.2 and $290 \mathrm{mg}$ GAE $100 \mathrm{~g}^{-1} \mathrm{fw}$ [66-69].

\subsection{Sugar Profile}

Significant differences among the "Pero de Cehegín" clones and "Fuji" and "Golden Delicious" varieties were found for sucrose and fructose. Sucrose content in the "Pero de Cehegín" was higher than in commercial varieties, while fructose was the opposite. For glucose, no differences were observed. In apples, D-fructose has been reported as the principal sugar, independently of the variety $[25,27,70,71]$. Conversely, "Pero de Cehegín" had similar, and even higher, values of sucrose than fructose as the main sugars, well above glucose. This sucrose:fructose ratio can be defined as a distinctive characteristic for this variety.

\subsection{Sensory Evaluation}

The mean values obtained in the sensory evaluation of the different organoleptic attributes of "Pero de Cehegín" clones are presented in Figure 2. For "Pero de Cehegín" appearance attributes, the panelists provided scores ranging from 5.00 (P1) to 8.00 (P3) for peel color, but notably lower than the Fuji variety (14.20). The homogeneity for peel color in "Pero de Cehegín" ranged between 6.2 (P3 and P4) and 8.4 (P2). For odor related attributes, P3 clone obtained the highest value for apple and 
fruity odor (the most characteristic odor of this fruit), while P1 and P2 clones showed the highest pineapple odor values. The highest values of quince and pear notes were provided for the "Golden Delicious" variety. Additionally, related to the other attributes, the "Pero de Cehegín" clones showed low sourness, high astringency, corking and fibrosity, and medium crispy when compared with Golden "Delicious" and "Fuji" varieties. The sourness perception in the sensory analysis was in agreement with the total titratable acidity (TA) (Table 6), that is, smaller values for "Pero de Cehegín" clones (P1-P5) than "Golden Delicious" and "Fuji" varieties (used as controls). The high value of two attributes (corkiness and fibreness) of the "Pero de Cehegín" clones must be highlighted. The high intensity of these attributes could be a disadvantage for fresh fruit consumption, such as apple or quince [72]. On the other hand, these values can be related to the highest values of firmness (F) (Table 4) for "Pero de Cehegín" clones. However, in the sensory analysis, a higher level of hardness for "Pero de Cehegín" clones and "Golden Delicious" and "Fuji" samples was not observed. In this sense, the firmness test can be considered as an indirect measurement to predict the consumer's perception on the texture of the fruit, and contradictory results have been published [73], indicating the importance of comparing the analytical methods with the sensory ones.

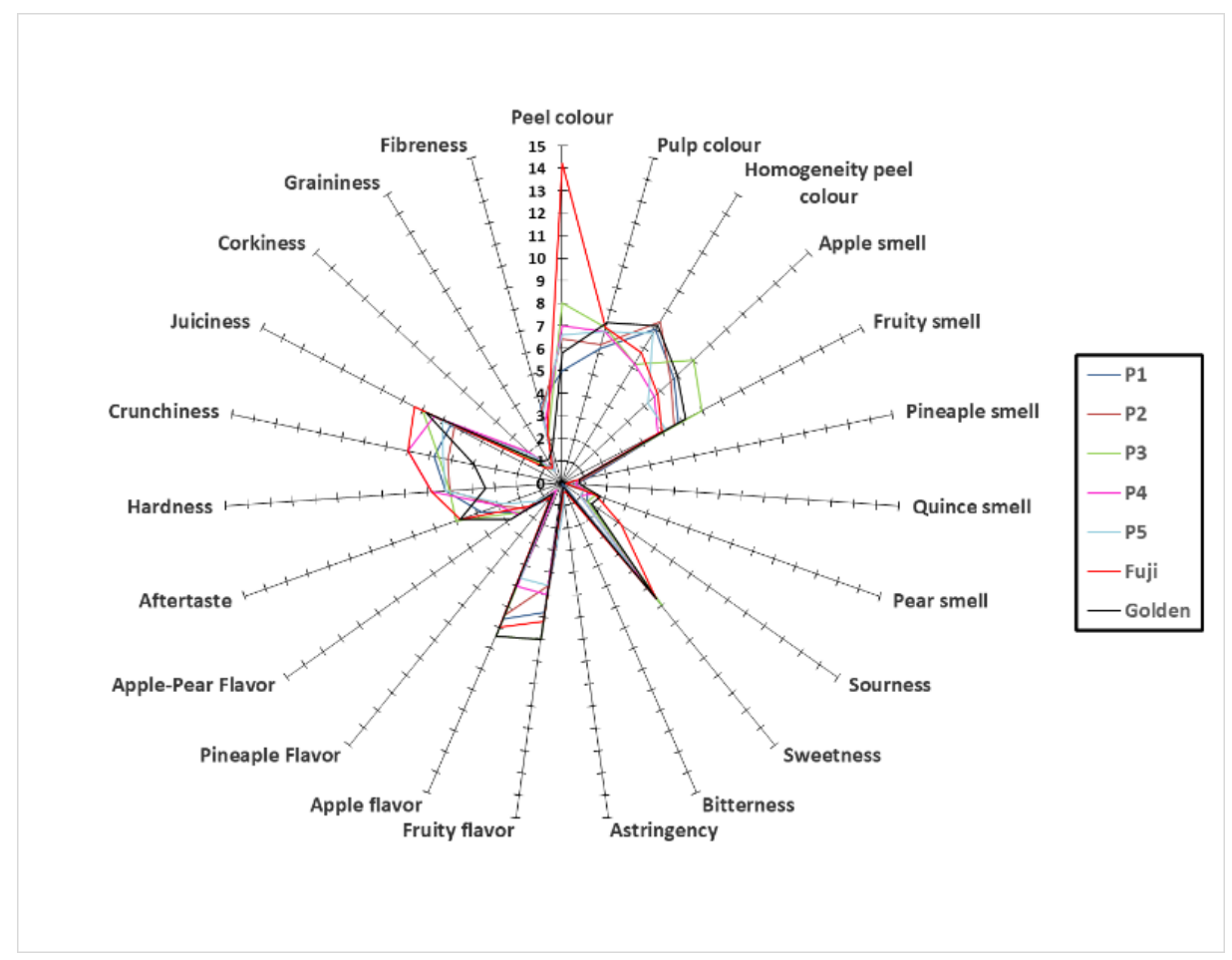

Figure 2. Sensory scores the five clones of "Pero de Cehegín" and two varieties of reference ("Fuji" and "Golden Delicious") harvested at maturity in 2017. Sensory scores ranged from 0 (not detectable) to 10 (strong), except color which ranges between 0 and 20.

\subsection{Principal Component Analysis}

Aiming to easily explain the trends and relationships among the measured variables (32) for all clones and varieties (7), a principal component analysis (PCA) was performed. The first five components explained $96.23 \%$ of the variation, while the first three components explained $82.89 \%$ of the total observed variability (Table 7). The first component, PC1 (40.64\% of the total variance), was related to TA, MI, F, H1, H2, AH, sucrose, and fructose. (Table 7, Figure 3). PC2 (27.55\% of the total variance) was related with the color coordinates $\mathrm{L}^{*}, \mathrm{a}^{*}, \mathrm{~b}^{*} \mathrm{C}^{*}$, and $\mathrm{H}^{\circ}$ (color), and FW, D1, D2, AD (weight and fruit size), CCw. PC3 (14.70\% of the total variance) was related to polyphenols, moisture, and CCd. The rest of the PCs were related to the traits highlighted in Table 7. 
Table 7. Eigenvalues, proportion of variation and eigenvectors associated with principal components of the principal component analysis (PCA).

\begin{tabular}{|c|c|c|c|c|c|c|}
\hline Principal Components (Axes) & 1 & 2 & 3 & 4 & 5 & 6 \\
\hline Proportion of variation & 39.54 & 27.76 & 15.13 & 7.97 & 5.72 & 3.88 \\
\hline Cumulative proportion of variation & 39.54 & 67.30 & 82.43 & 90.40 & 96.12 & 100 \\
\hline Variable & \multicolumn{6}{|c|}{ Eigenvectors } \\
\hline FW (Fruit weight) & 0.147 & -0.241 & 0.148 & 0.008 & -0.235 & -0.168 \\
\hline D1 (Equatorial diameter 1) & 0.175 & -0.221 & 0.203 & 0.064 & 0.024 & 0.007 \\
\hline D2 (Equatorial diameter 2) & 0.068 & -0.271 & 0.250 & 0.068 & -0.066 & -0.026 \\
\hline AD (Average equatorial diameter) & 0.135 & -0.242 & 0.234 & 0.068 & 0.028 & 0.018 \\
\hline H1 (Fruit height 1) & 0.262 & -0.058 & 0.120 & 0.029 & -0.159 & -0.123 \\
\hline H2 (Fruit height 2) & 0.237 & -0.134 & 0.108 & 0.041 & -0.226 & -0.089 \\
\hline AH (Average fruit height) & 0.253 & -0.093 & 0.115 & 0.035 & -0.191 & -0.109 \\
\hline PCw (Width of the pedicle cavity) & 0.233 & -0.090 & 0.030 & 0.239 & -0.258 & 0.004 \\
\hline PCd (Depth of the pedicle cavity) & -0.008 & 0.191 & -0.167 & 0.299 & 0.003 & -0.528 \\
\hline CCw (Width of the calycine cavity) & 0.135 & -0.238 & 0.180 & -0.020 & 0.274 & 0.030 \\
\hline CCd (Depth of the calyx cavity) & -0.193 & 0.158 & 0.263 & 0.026 & -0.032 & -0.013 \\
\hline OL (Aperture of locules) & 0.142 & -0.078 & 0.158 & 0.037 & 0.539 & 0.227 \\
\hline Sv (Number of viable seeds) & -0.180 & 0.085 & 0.205 & 0.210 & -0.084 & -0.412 \\
\hline Sa (Number of abortive seeds) & 0.062 & -0.032 & -0.026 & 0.564 & 0.113 & 0.333 \\
\hline F (Firmness) & 0.233 & 0.134 & -0.168 & -0.134 & -0.029 & 0.014 \\
\hline TSS (Total soluble solids) & 0.129 & -0.138 & -0.228 & -0.373 & -0.150 & 0.047 \\
\hline TA (Total titratable acidity) & -0.253 & -0.150 & 0.043 & 0.064 & -0.047 & 0.000 \\
\hline MI (Maturity index) & 0.236 & 0.114 & -0.129 & -0.218 & 0.063 & -0.034 \\
\hline Moisture & -0.151 & 0.068 & 0.374 & -0.057 & -0.041 & 0.108 \\
\hline L*(Lightness) (D65) & 0.124 & 0.286 & 0.148 & 0.001 & 0.002 & -0.075 \\
\hline a * (Red-greenness) (D65) & -0.173 & -0.250 & -0.135 & -0.026 & 0.001 & -0.083 \\
\hline b* (Blue-yellowness) (D65) & 0.123 & 0.286 & 0.153 & -0.014 & -0.030 & 0.019 \\
\hline$C^{*}$ (Chromaticity) (D65) & 0.101 & 0.295 & 0.157 & -0.035 & -0.056 & 0.019 \\
\hline $\mathrm{H}^{\circ}$ (Hue angle) (D65) & 0.165 & 0.257 & 0.139 & 0.022 & 0.001 & 0.062 \\
\hline $\mathrm{ABTS}^{+}$ & 0.229 & -0.043 & 0.046 & -0.024 & 0.369 & -0.275 \\
\hline $\mathrm{DPPH}^{\bullet}$ & 0.066 & 0.027 & -0.320 & 0.415 & 0.141 & 0.001 \\
\hline TP (Total phenolic) & -0.068 & 0.202 & 0.304 & -0.190 & 0.186 & -0.077 \\
\hline FRAP & 0.239 & 0.028 & -0.058 & -0.035 & 0.310 & -0.298 \\
\hline Sucrose & 0.268 & 0.030 & -0.080 & -0.088 & -0.119 & 0.174 \\
\hline Glucose & -0.102 & -0.258 & -0.091 & -0.190 & 0.189 & -0.298 \\
\hline Fructose & -0.242 & -0.149 & 0.131 & -0.054 & 0.036 & -0.051 \\
\hline
\end{tabular}

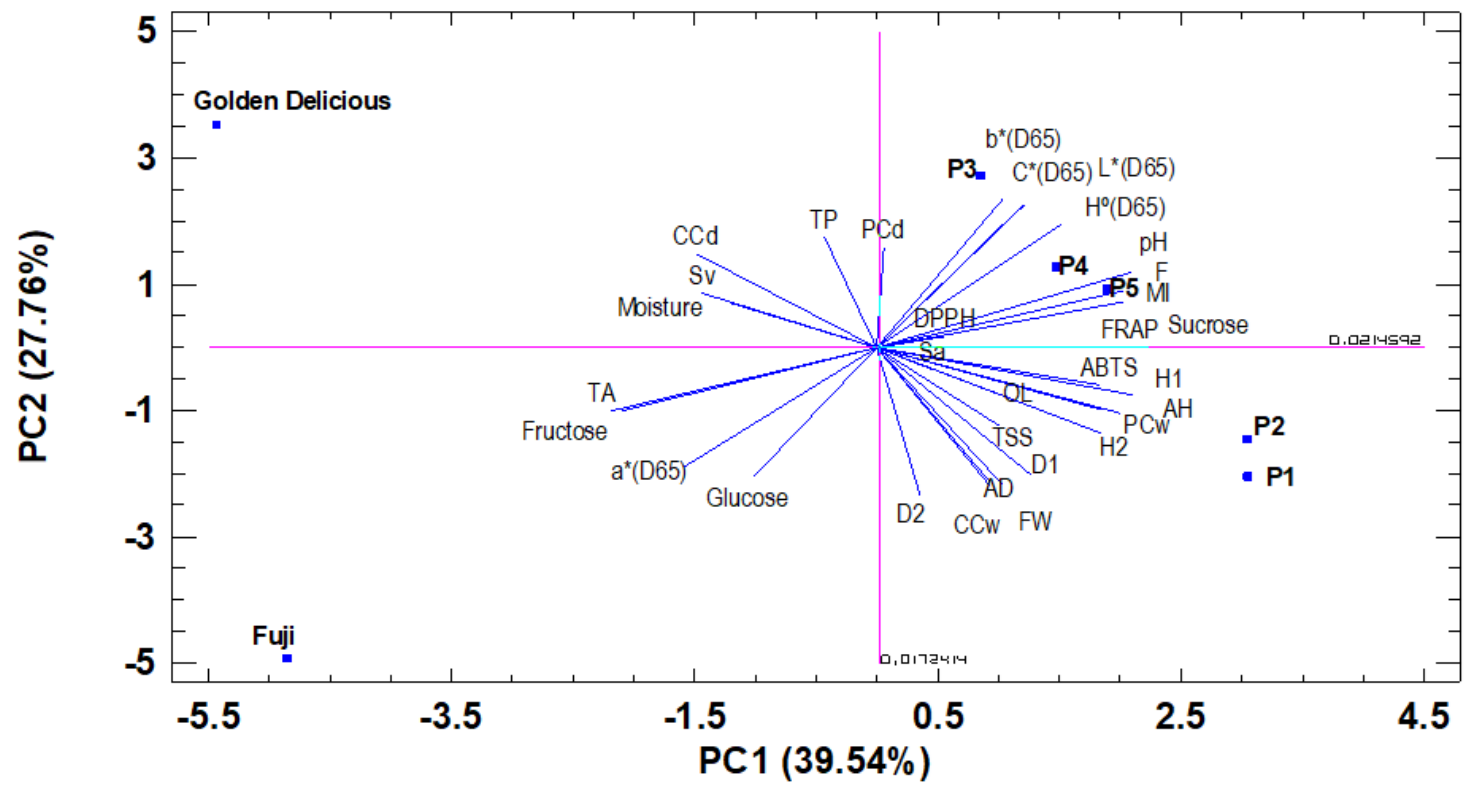

Figure 3. PCA of the measured parameters. Biplot PC1-PC2. 
The PC1-PC2 biplot (Table 7, Figure 3), separated "Fuji" and "Golden Delicious" varieties, located on the negative $X$-axis (PC1), from the "Pero de Cehegín" clones, located on the positive X-axis. In the same way, and for the "Pero de Cehegín" clones, the results separated the P1 and P2 clones, placed on the negative $Y$-axis (PC2) and very close to each other, from the rest of the clones, placed on the positive $Y$-axis.

The results obtained from the hierarchical cluster analysis, using the linkage method between groups, were shown as a dendrogram (Figure 4), with two branches separating "Pero de Cehegín" clones from commercial varieties. Then, "Pero de Cehegín" clones were grouped into two groups. The first group consisted of clones P1 and P2, while the second group include clones P3, P4, and P5. The dendrogram obtained by the cluster analysis matches with results of the principal component analysis (PCA).

Dendrogram

Ward's Method,Squared Euclidean

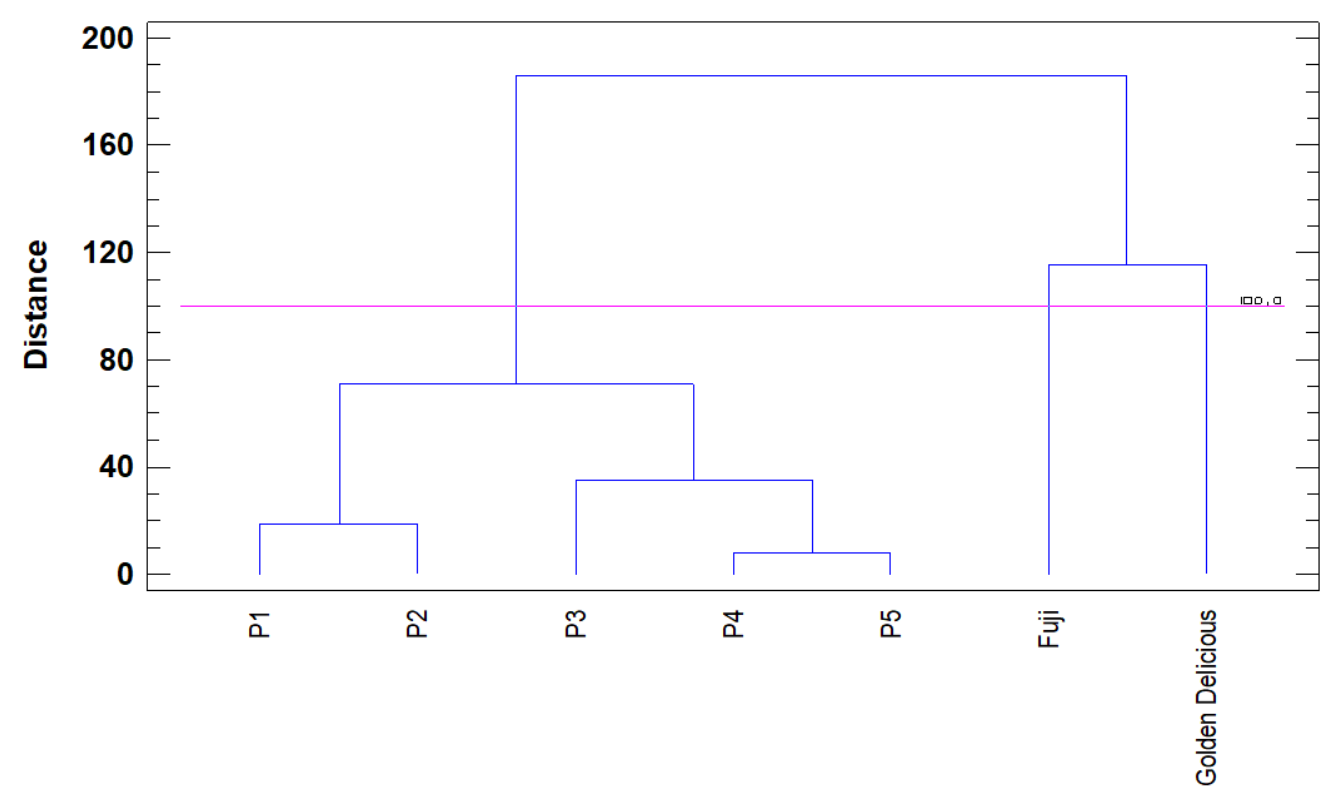

Figure 4. Dendrogram constructed with the number of physicochemical traits evaluated following Ward's method. Squared Euclidean distance represents dissimilarity.

\section{Conclusions}

This study allowed identifying the "Pero de Cehegín" as a unique and new genotype, not reported in the Spanish germplasm banks and revealed the interest in continuing with apple prospection work in Spanish areas of the Southeast which has not been sufficiently explored.

The study of the physicochemical characteristics, bioactive compounds, and sensory profile of five clones of "Pero de Cehegín" has allowed observing the existence of variability between clones. An important variability was found for fruit weight, diameter, and height between the different "Pero de Cehegín" clones. In comparison with "Fuji" and "Golden Delicious", "Pero de Cehegín" showed high firmness, high total soluble solids, very low total acidity, high FRAP antioxidant capacity, and more sucrose content. These distinctive characteristics and its good appearance and special odor make this variety a marketable product that with an adequate evaluation and diffusion can increase the market offering and complement the demand for new products, thereby opening the possibility of spreading its cultivation in areas where it can be adapted. This is a preliminary study, so to confirm the phenotypic characterization, this study will continue for two more years. 
Author Contributions: Conceptualization and methodology, R.M. and P.M.; formal analysis, data collection and writing-original draft preparation, R.M.; validation and writing—review and editing, P.L., F.H., Á.C.-B., Y.G., J.J.M.-N. and P.M.; experimental analysis, R.M. and Y.G.; supervision, P.M. All authors have read and agreed to the published version of the manuscript.

Funding: This research received no external funding.

Acknowledgments: All the authors thank Alvaro Blanco for his work as responsible for the Germplasm Bank of Manzano of the EEAD which maintenance was partially supported by INIA (Instituto Nacional de Investigación y Tecnología Agraria y Alimentaria), under the Project: RF2011-00017-C05-05. The authors appreciate the technical help provided by Hiba Ghrissi, Abel Morera, Davíd López, and Carlos Lahoz. Partial support was obtained from the Spanish State Research Agency (AEI) co-financed with the European Regional Development Fund (FEDER) (project AGL2017-83358-R to Y.G; AEI/FEDER, UE), and the Aragón Government (Group A09-20R). The authors acknowledge the Spanish National Research Council (CSIC) for the IOAP discount.

Conflicts of Interest: The authors declare no conflict of interest.

\section{References}

1. Strasburger, E.; Noll, F.; Schenk, H. Tratado de Botánica, 7th ed.; Omega, AFW Schinder -Ediciones: Barcelona, Spain, 1990; ISBN 978-8-4282-0873-4.

2. Chevalier, A.C. L'origine des Poiriers et Pommiers sauvages de nos forêts et la part qu'ils ont prise dans la formation des variétés cultivées. Rev. Int. Bot. Appl. d'Agric. Trop. 1953, 33, 583-585.

3. Cornille, A.; Gladieux, P.; Smulders, M.J.M.; Roldán-Ruiz, I.; Laurens, F.; Le Cam, B.; Nersesyan, A.; Clavel, J.; Olonova, M.; Feugey, L.; et al. New Insight into the History of Domesticated Apple: Secondary Contribution of the European Wild Apple to the Genome of Cultivated Varieties. PLoS Genet. 2012, 8, e1002703. [CrossRef] [PubMed]

4. Harrison, N.; Harrison, R.J. On the evolutionary history of the domesticated apple. Nat. Genet. 2011, 43, 1043-1044. [CrossRef] [PubMed]

5. Reim, S.; Proft, A.; Heinz, S.; Höfer, M. Diversity of the European indigenous wild apple Malus sylvestris (L.) Mill. in the East Ore Mountains (Osterzgebirge), Germany: I. Morphological characterization. Genet. Resour. Crop. Evol. 2011, 59, 1101-1114. [CrossRef]

6. FAOSTAT. Available online: http://www.fao.org/faostat/es/\#data/QC (accessed on 7 July 2020).

7. MAPA. Available online: https://www.mapa.gob.es/es/estadistica/temas/publicaciones/anuario-deestadistica/ (accessed on 7 July 2020).

8. MAPA. Available online: https://www.mapa.gob.es/es/agricultura/temas/producciones-agricolas/frutas-yhortalizas/informacion_general.aspx (accessed on 7 July 2020).

9. Rivera, N.; Obón, C.; Ríos, S.; Selma, C.; Méndez, F.; Verde, A.; Cano, F. Frutos Secos, Oleaginosos, Frutales de Hueso, Almendros y Frutales de Pepita: Las Variedades Tradicionales de la Cuenca del río Segura, Catálogo Etnobotánico I; University of Murcia: Murcia, Spain, 1997; ISBN 978-8-4768-4744-2.

10. Martínez, R.; Melgarejo, P. El “Pero de cehegín” (Malus domestica Borckh.). Agríc. Vergel 2008, 320, $373-377$.

11. Harlan, J.R. Geographic Patterns of Variation in Some Cultivated Plants. J. Hered. 1975, 66, $182-191$. [CrossRef]

12. Harlan, J.R. Our Vanishing Genetic Resources. Science 1975, 188, 617-621. [CrossRef]

13. Stanivuković, S.; Žujić, M.; Žabić, M.; Mićić, N.; Bosancic, B.; Đurić, G. Characterization of Old Apple Cultivars from Bosnia and Herzegovina by Means of Pomological and Biochemical Analysis. Not. Bot. Horti Agrobot. Cluj-Napoca 2017, 45, 97-104. [CrossRef]

14. Mitre, I.; Mitre, V.; Ardelean, M.; Sestras, R.; Sestras, A. Evaluation of old apple cultivars grown in Central Transylvania, Romania. Not. Bot. Horti Agrobot. Cluj-Napoca 2009, 37, 235-237. [CrossRef]

15. Dan, C.; Șerban, C.; Sestraş, A.F.; Militaru, M.; Morariu, P.; Sestraş, R.E. Consumer Perception Concerning Apple Fruit Quality, Depending on Cultivars and Hedonic Scale of Evaluation-A Case Study. Not. Sci. Biol. 2015, 7, 140-149. [CrossRef]

16. Martínez, R. Caracterización varietal del "Pero de Cehegín" (Malus domestica Borkh). In Trabajo Final de Carrera; EPSO-Miguel Hernandez University: Orihuela, Spain, 2000.

17. Goulão, L.; Oliveira, C.M. Molecular characterisation of cultivars of apple (Malus $\times$ domestica Borkh.) using microsatellite (SSR and ISSR) markers. Euphytica 2001, 122, 81-89. [CrossRef] 
18. Patzak, J.; Paprštein, F.; Henychová, A.; Sedlák, J. Comparison of genetic diversity structure analyses of SSR molecular marker data within apple (Malus $\times$ domestica) genetic resources. Genome 2012, 55, $647-665$. [CrossRef] [PubMed]

19. Pérez-Romero, L.; Suárez, M.; Dapena, E.; Rallo, P. Molecular and morphological characterization of local apple cultivars in Southern Spain. Genet. Mol. Res. 2015, 14, 1487-1501. [CrossRef]

20. Mažeikienè, I.; Šikšnianienè, J.B.; Baniulis, D.; Gelvonauskienė, D.; Frercks, B.; Starkus, A.; Žebrauskienè, A.; Stanys, V. SSR analysis based on molecular characterisation of apple germplasm in Lithuania. Zemdirb. -Agric. 2019, 106, 159-166. [CrossRef]

21. Yun, W.; Ban, S.; Kim, G.; Kim, J.-H.; Kwon, S.; Choi, C. Assessment of apple core collections constructed using phenotypic and genotypic data. Genet. Mol. Res. 2015, 14, 6453-6464. [CrossRef] [PubMed]

22. Lassois, L.; Denancé, C.; Ravon, E.; Guyader, A.; Guisnel, R.; Hibrand-Saint-Oyant, L.; Poncet, C.; Lasserre-Zuber, P.; Feugey, L.; Durel, C.-E. Genetic Diversity, Population Structure, Parentage Analysis, and Construction of Core Collections in the French Apple Germplasm Based on SSR Markers. Plant Mol. Biol. Rep. 2016, 34, 827-844. [CrossRef]

23. Pereira-Lorenzo, S.; Urrestarazu, J.; Ramos-Cabrer, A.; Miranda, C.; Pina, A.; Dapena, E.; Moreno, M.Á.; Errea, P.; Llamero, N.; Hernández, M.B.D.; et al. Analysis of the genetic diversity and structure of the Spanish apple genetic resources suggests the existence of an Iberian genepool. Ann. Appl. Biol. 2017, 171, 424-440. [CrossRef]

24. Marconi, G.; Ferradini, N.; Russi, L.; Concezzi, L.; Veronesi, F.; Albertini, E. Genetic Characterization of the Apple Germplasm Collection in Central Italy: The Value of Local Varieties. Front. Plant Sci. 2018, 9, 9. [CrossRef]

25. Wu, J.; Gao, H.; Zhao, L.; Liao, X.; Chen, F.; Wang, Z.; Hu, X.S. Chemical compositional characterization of some apple cultivars. Food Chem. 2007, 103, 88-93. [CrossRef]

26. Serra, A.T.; Matias, A.A.; Frade, R.; Duarte, R.O.; Feliciano, R.; Bronze, M.R.; Figueira, M.E.; De Carvalho, A.; Duarte, C. Characterization of traditional and exotic apple varieties from Portugal. Part 2-Antioxidant and antiproliferative activities. J. Funct. Foods 2010, 2, 46-53. [CrossRef]

27. Feliciano, R.P.; Antunes, C.; Ramos, Á.; Serra, A.T.; Figueira, M.E.; Duarte, C.M.M.; De Carvalho, A.; Bronze, M.R. Characterization of traditional and exotic apple varieties from Portugal. Part 1-Nutritional, phytochemical and sensory evaluation. J. Funct. Foods 2010, 2, 35-45. [CrossRef]

28. Seipel, M.; Pirovani, M.E.; Güemes, D.R.; Gariglio, N.F.; Piagentini, A.M. Características Fisicoquímicas de los Frutos de Tres Variedades de Manzanas Cultivadas en la Región Centro-Este de la Provincia de Santa Fe. FAVE Secc. Cienc. Agrar. 2009, 8, 27-36. [CrossRef]

29. Vieira, F.G.K.; Borges, G.D.S.C.; Copetti, C.; Amboni, R.D.D.M.C.; Denardi, F.; Fett, R. Physico-chemical and antioxidant properties of six apple cultivars (Malus domestica Borkh) grown in southern Brazil. Sci. Hortic. 2009, 122, 421-425. [CrossRef]

30. Kotiyal, A.; Dimri, D.C.; Goswami, A.P. Physico-chemical evaluation of ten apple (Malus domestica, Borkh.) cultivars grown in uttarakhand hills of India. Plant Arch. 2017, 17, 573-579.

31. Hassan, S.; Bhat, K.M.; Dar, Z.A.; Mir, M.A.; Pandith, A.H.; Wani, W.M.; Jan, A. Morphological characterization of apple accessions in Kashmir region. Plant Arch. 2017, 17, 1071-1077.

32. Alberti, A.; Zielinski, A.A.F.; Couto, M.; Judacewski, P.; Igarashi-Mafra, L.; Nogueira, A. Distribution of phenolic compounds and antioxidant capacity in apples tissues during ripening. J. Food Sci. Technol. 2017, 54, 1511-1518. [CrossRef]

33. Musacchi, S.; Serra, S. Apple fruit quality: Overview on pre-harvest factors. Sci. Hortic. 2018, 234, 409-430. [CrossRef]

34. Papadakis, J. (Ed.) Climates of the World and Their Potentialities; Libro de Edicion Argentina: Buenos Aires, Argentina, 1975.

35. Lateur, M.; Ordidge, M.; Engels, J.; Lipman, E. Report of a Working Group on Malus/Pyrus. In Proceedings of the Report of a Working Group on Malus/Pyrus. Fourth Meeting, Rome, Italy, 7-9 March 2012; Bioversity International: Weggis, Switzerland, 2013; pp. 7-9.

36. Urrestarazu, J.; Miranda, C.; Santesteban, L.G.; Royo, J.B. Genetic diversity and structure of local apple cultivars from Northeastern Spain assessed by microsatellite markers. Tree Genet. Genomes 2012, 8, 1163-1180. [CrossRef] 
37. International Union for the Protection of New Varieties of Plants (UPOV). Guidelines for the Conduct of Tests for Distinctness, Uniformity and Stability. Apple. Technical Guideline TG/14/9. Available online: https://www.upov.int/edocs/tgdocs/en/tg014.pdf (accessed on 10 March 2020).

38. Horwitz, W.; Latimer, G. Official Methods of Analysis of AOAC International, 18th ed.; A.O.A.C International: Gaithersburg, MD, USA, 2005; ISBN 978-0-9355-8475-2.

39. Re, R.; Pellegrini, N.; Proteggente, A.; Pannala, A.; Yang, M.; Rice-Evans, C. Antioxidant activity applying an improved ABTS radical cation decolorization assay. Free Radic. Biol. Med. 1999, 26, 1231-1237. [CrossRef]

40. Benzie, I.; Strain, J. The Ferric Reducing Ability of Plasma (FRAP) as a Measure of "Antioxidant Power": The FRAP Assay. Anal. Biochem. 1996, 239, 70-76. [CrossRef]

41. Brand-Williams, W.; Cuvelier, M.; Berset, C. Use of a free radical method to evaluate antioxidant activity. LWT 1995, 28, 25-30. [CrossRef]

42. Nuncio-Jáuregui, N.; Munera-Picazo, S.; Calín-Sánchez, Á.; Wojdylo, A.; Hernández, F.; Carbonell-Barrachina, A. Bioactive compound composition of pomegranate fruits removed during thinning. J. Food Compos. Anal. 2015, 37, 11-19. [CrossRef]

43. Singleton, V.L.; Orthofer, R.; Lamuela-Raventos, R.M. [14] Analysis of total phenols and other oxidation substrates and antioxidants by means of folin-ciocalteu reagent. Methods Enzymol. 1999, 299, 152-178. [CrossRef]

44. Hernandez, F.; Noguera-Artiaga, L.; Burló, F.; Wojdylo, A.; Carbonell-Barrachina, A.; Legua, P. Physico-chemical, nutritional, and volatile composition and sensory profile of Spanish jujube (Ziziphus jujuba Mill.) fruits. J. Sci. Food Agric. 2015, 96, 2682-2691. [CrossRef]

45. Hokanson, S.C.; Szewc-McFadden, A.K.; Lamboy, W.F.; McFerson, J.R. Microsatellite (SSR) markers reveal genetic identities, genetic diversity and relationships in a Malus $\times$ domestica borkh. core subset collection. Theor. Appl. Genet. 1998, 97, 671-683. [CrossRef]

46. Liebhard, R.; Gianfranceschi, L.E.A.; Koller, B.; Ryder, C.; Tarchini, R.; Van De Weg, E.; Gessler, C. Development and characterisation of 140 new microsatellites in apple (Malus x domestica Borkh.). Mol. Breed. 2002, 10, 217-241. [CrossRef]

47. Silfverberg-Dilworth, E.; Matasci, C.L.; Van De Weg, W.E.; Van Kaauwen, M.P.W.; Walser, M.; Kodde, L.P.; Soglio, V.; Gianfranceschi, L.; Durel, C.E.; Costa, F.; et al. Microsatellite markers spanning the apple (Malus $x$ domestica Borkh.) genome. Tree Genet. Genomes 2006, 2, 202-224. [CrossRef]

48. University of Lleida. UdL Banco de Germoplasma-Identificación Molecular. Available online: http://www. fruticultura.udl.es/Fruticultura/bancGermoplasma/identificacioMolecular.html (accessed on 17 July 2020).

49. Ferreira, V.; Ramos-Cabrer, A.M.; Carnide, V.; Pinto-Carnide, O.; Assunção, A.; Marreiros, A.; Rodrigues, R.; Pereira-Lorenzo, S.; Castro, I. Genetic pool structure of local apple cultivars from Portugal assessed by microsatellites. Tree Genet. Genomes 2016, 12, 1-15. [CrossRef]

50. Höller, I.; Guerra, W.; Gummerer, K. Spezifisches Gewicht neuer Apfelsorten Specific Weight of New Apple Varieties. Erwerbs-Obstbau 2017, 59, 85-91. [CrossRef]

51. Kim, K.-B.; Lee, S.; Kim, M.-S.; Cho, B.-K. Determination of apple firmness by nondestructive ultrasonic measurement. Postharvest Biol. Technol. 2009, 52, 44-48. [CrossRef]

52. Iwanami, H. Breeding for Fruit Quality in Apple; Wiley: Hoboken, NJ, USA, 2011; pp. 173-200.

53. Hampson, C.R.; Sanford, K.; Cline, J. Preferences of Canadian consumers for apple fruit size. Can. J. Plant Sci. 2002, 82, 165-167. [CrossRef]

54. Varela, P.; Salvador, A.; Fiszman, S. Shelf-life estimation of 'Fuji' apples: Sensory characteristics and consumer acceptability. Postharvest Biol. Technol. 2005, 38, 18-24. [CrossRef]

55. Harker, F.; Maindonald, J.; Murray, S.; Gunson, A.; Hallett, I.; Walker, S. Sensory interpretation of instrumental measurements 1: Texture of apple fruit. Postharvest Biol. Technol. 2002, 24, 225-239. [CrossRef]

56. Brookfield, P.L.; Nicoll, S.; Gunson, A.; Harker, F.; Wohlers, M. Sensory evaluation by small postharvest teams and the relationship with instrumental measurements of apple texture. Postharvest Biol. Technol. 2011, 59, 179-186. [CrossRef]

57. Singh, N.; Dhanoa, D. NS Sodhi Physico-chemical and textural properties of apples from different cultivars. J. Food Sci. Technol. 2006, 43, 127-129.

58. Łata, B. Relationship between Apple Peel and the Whole Fruit Antioxidant Content: Year and Cultivar Variation. J. Agric. Food Chem. 2007, 55, 663-671. [CrossRef] 
59. Mikulic-Petkovsek, M.; Stampar, F.; Veberic, R. Parameters of inner quality of the apple scab resistant and susceptible apple cultivars (Malus domestica Borkh.). Sci. Hortic. 2007, 114, 37-44. [CrossRef]

60. Reig, G.; Blanco, Á.; Castillo, A.M.; Gogorcena, Y.; Moreno, M. Ángeles Phenotypic diversity of Spanish apple (Malus $x$ domestica Borkh) accessions grown at the vulnerable climatic conditions of the Ebro Valley, Spain. Sci. Hortic. 2015, 185, 200-210. [CrossRef]

61. Hagen, S.F.; Borge, G.I.A.; Bengtsson, G.; Bilger, W.; Berge, A.; Haffner, K.; Solhaug, K.A. Phenolic contents and other health and sensory related properties of apple fruit (Malus domestica Borkh., cv. Aroma): Effect of postharvest UV-B irradiation. Postharvest Biol. Technol. 2007, 45, 1-10. [CrossRef]

62. Drogoudi, P.; Michailidis, Z.; Pantelidis, G. Peel and flesh antioxidant content and harvest quality characteristics of seven apple cultivars. Sci. Hortic. 2008, 115, 149-153. [CrossRef]

63. Kingston, C.M. Maturity Indices for Apple and Pear. Hortic. Rev. 2010, 13, 407-432. [CrossRef]

64. Bai, Y.; Dougherty, L.; Cheng, L.; Zhong, G.-Y.; Xu, K. Uncovering co-expression gene network modules regulating fruit acidity in diverse apples. BMC Genom. 2015, 16, 612. [CrossRef] [PubMed]

65. Scalzo, J.; Politi, A.; Pellegrini, N.; Mezzetti, B.; Battino, M. Plant genotype affects total antioxidant capacity and phenolic contents in fruit. Nutrition 2005, 21, 207-213. [CrossRef]

66. Eberhardt, M.V.; Lee, C.Y.; Liu, R.H. Antioxidant activity of fresh apples. Natural 2000, 405, $903-904$. [CrossRef] [PubMed]

67. Wolfe, K.; Wu, X.; Liu, R.H. Antioxidant Activity of Apple Peels. J. Agric. Food Chem. 2003, 51, 609-614. [CrossRef] [PubMed]

68. Vrhovsek, U.; Rigo, A.; Tonon, D.; Mattivi, F. Quantitation of Polyphenols in Different Apple Varieties. J. Agric. Food Chem. 2004, 52, 6532-6538. [CrossRef]

69. Vieira, F.G.K.; Borges, G.D.S.C.; Copetti, C.; Gonzaga, L.V.; Nunes, E.; Fett, R. Activity and contents of polyphenolic antioxidants in the whole fruit, flesh and peel of three apple cultivars. Arch. Latinoam. Nutr. 2009, 59, 101-106.

70. Karadeniz, F.; Ekşi, A. Sugar composition of apple juices. Eur. Food Res. Technol. 2002, 215, 145-148. [CrossRef]

71. Sanz, M.L.; Villamiel, M.; Martínez-Castro, I. Inositols and carbohydrates in different fresh fruit juices. Food Chem. 2004, 87, 325-328. [CrossRef]

72. Szychowski, P.J.; Munera-Picazo, S.; Szumny, A.; Carbonell-Barrachina, A.; Hernández, F. Quality parameters, bio-compounds, antioxidant activity and sensory attributes of Spanish quinces (Cydonia oblonga Miller). Sci. Hortic. 2014, 165, 163-170. [CrossRef]

73. Harker, F.; Gunson, A.; Brookfield, P.L.; White, A. An apple a day: The influence of memory on consumer judgment of quality. Food Qual. Prefer. 2002, 13, 173-179. [CrossRef] 